\title{
Dredging of an active thickened tailings storage facility at the Ernest Henry Mine
}

\author{
TG Fitton Fitton Tailings Consultants, Australia \\ WJ Neumann Neumann Contractors Pty Ltd, Australia
}

\begin{abstract}
After some 15 years of operation as a copper and gold mine, the Ernest Henry Mine installed a magnetite extraction plant to enable the recovery of magnetite concentrate as well. A study was carried out to determine the feasibility of re-mining the tailings from an active thickened tailings storage area, which proved it viable. Dredging, dry mining and hydro mining methods of extraction were examined, costed and compared. Dredging was the selected method. In the months to follow, a dredging operation was set up on the tailings storage facility, which mined magnetite-rich tailings from it whilst simultaneously enabling the storage facility to remain active for receiving the thickened barren tailings from the magnetite extraction plant.

The Ernest Henry tailings storage facility is a square-shaped thickened discharge system with a perimeter embankment, and a beach that slopes from one corner to the opposite one. This slope of the beach presented one challenge to the dredging operation, which was effectively addressed with the adoption of a systematic progressive mining method. The need to minimise the sterilisation of the magnetite-rich tailings beneath a layer of new barren tailings presented another challenge, which also required some careful planning.

An overview of the dredging operation is presented, as well as some relevant details of it. The management of the tailings discharge during dredging is also discussed, as is the slurry transport and pumping requirements for the dredging. A number of other technical and practical challenges are also discussed, such as the initial excavation of the starter pond, launching and retrieving the dredge, and anchoring of the dredge.
\end{abstract}

Dredging can be a very effective and economical means of extracting tailings from a storage facility, even in cases where thickened tailings have been discharged to create a sloping beach.

\section{$1 \quad$ Introduction}

This paper presents a case study of a recent tailings dredging operation from an active thickened tailings storage facility (TSF) at the Ernest Henry Mine (EHM) in Queensland, Australia. The Ernest Henry tailings storage facility is a square-shaped thickened discharge system with a perimeter embankment, and a beach that slopes from one corner to the opposite one. This slope of the beach presented one challenge to the dredging operation, which was effectively addressed with the adoption of a systematic progressive mining method. The need to minimise the sterilisation of the magnetite-rich tailings beneath a layer of new barren tailings presented another challenge, which also required some careful planning. An overview of the dredging operation is presented, as well as some relevant details of it. The management of the tailings discharge during dredging is also discussed, as is the slurry transport and pumping requirements for the dredging. A number of other technical and practical challenges are also discussed, such as the initial excavation of the starter pond, launching and retrieving the dredge, and anchoring of the dredge.

\section{$2 \quad$ Background}

The Ernest Henry Mine has been operating for about 17 years. For the first 14 years of its life, copper concentrate with some gold content was the only product exported from the mine. Early in the mine life a 
thickened discharge system was selected for the storage of tailings, with the main driver being the minimisation of water consumption at the mine. The general area is flat and arid, making it well suited to the establishment of a central thickened discharge (CTD) type tailings storage facility. However, due to limitations on the amount of land available for the TSF, it was decided that a 1,700 $\mathrm{m}$ square-shaped cell-type TSF should be established on the site, with the thickened tailings slurry being discharged from its northwestern corner. This effectively created a quarter of a CTD with a beach that sloped towards the southeastern corner, with an average slope of about $0.8 \%$. The design of the perimeter embankments exploited the beach slope, with the height of the embankments being non-uniform in order to minimise unnecessary freeboard. These embankments have been periodically raised by the upstream method. Some six years into the mine life, an additional tailings cell was constructed immediately north of the first one, to provide some additional storage and some flexibility during embankment raising operations. This second cell was about 1,500 $\mathrm{m}$ long, but only $350 \mathrm{~m}$ wide. The tailings was discharged from the western end of this cell. In both cells, the operators had been constructing small training bunds in an effort to control the tailings deposition to a higher degree.

Decant water and rainfall runoff from each of the two tailings cells is not stored in each of the cells, but is instead directed into a separate water storage facility. Hence, neither of the two TSFs has a significant pond on its surface. However, a water table existed within the body of tailings, due to the retention capability of the perimeter bund and the elevation of the decant weir. The existence of this phreatic surface lessened the requirement for make-up water pumping as the dredge pond was deepened down into the water table, though this was affected by the limited permeability of the tailings.

A general arrangement of the tailings cells is presented as Figure 1.

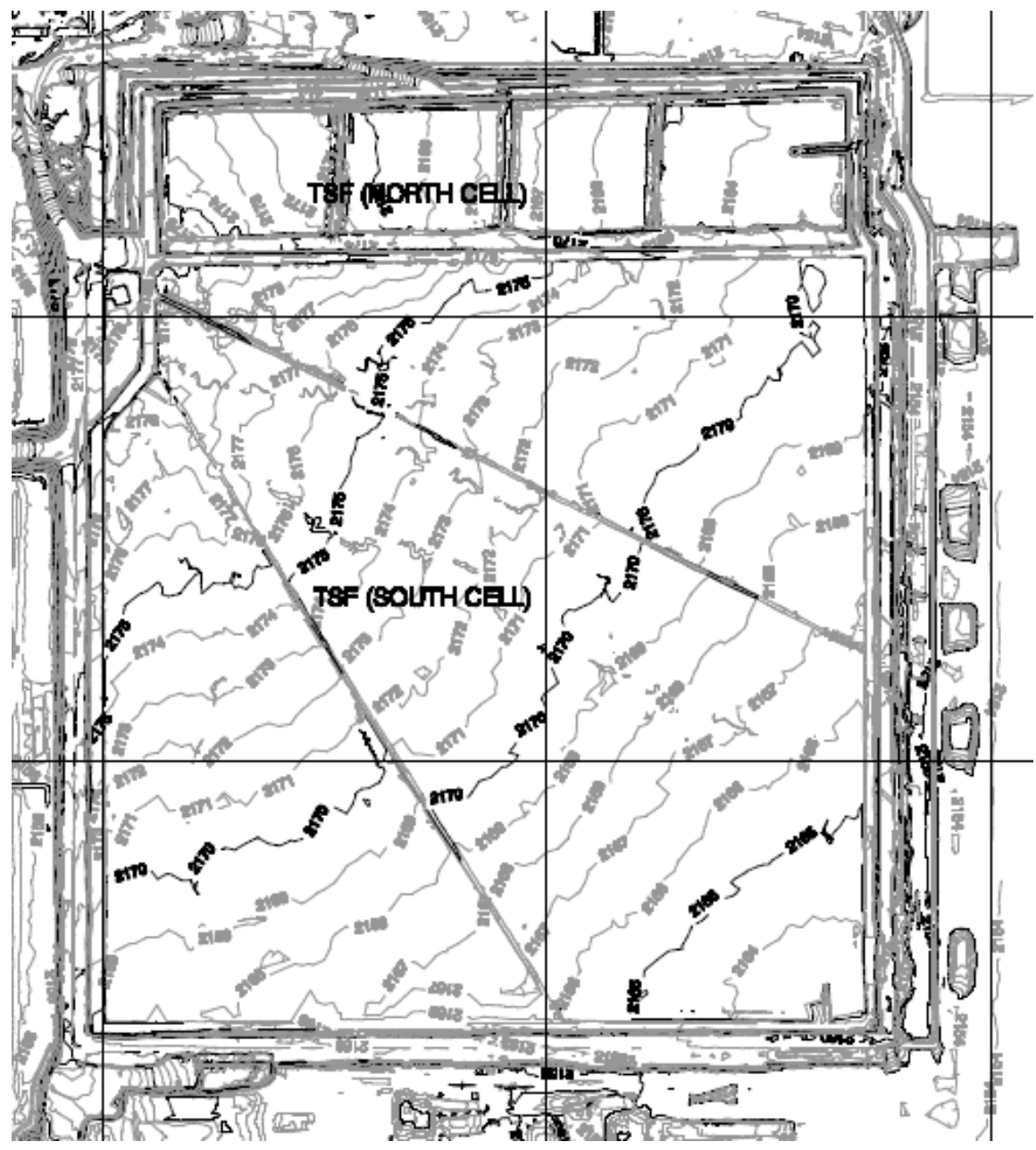

Figure 1 A layout of the two tailings cells at the Ernest Henry Mine, showing the topographic contours of the tailings surface after 14 years of storage 
About three years ago a magnetite extraction circuit was installed, and the mine commenced exporting magnetite concentrate as well. Shortly before the commissioning of the magnetite circuit, a study was carried out to determine the feasibility of extracting magnetite from the existing tailings whilst keeping the TSFs operational. Conventional dry mining, hydro mining and dredging were all considered for the re-mining of the tailings, with a conceptual design being developed for each method, and then a cost estimate being prepared for each one. Stability analysis was included in the study phase, and it was found that the dredging option had an advantage over the other two options, since the rate of drawdown of the phreatic surface would be lower, and could be controlled to a greater degree. The dredging option was selected on the basis of cost and risk. In the months to follow, a dredging operation was set up on the TSFs, which mined magnetite-rich tailings from the TSF whilst simultaneously enabling the storage facilities to remain active for receiving the thickened barren tailings from the magnetite extraction plant.

\section{Overview of the dredging work}

The type of dredge used at Ernest Henry is known as a cutter suction dredge (CSD). Typically a CSD floats on a water body, has slurry pumping equipment on board and has a cutting device near the intake of the suction pipe. The cutter loosens the soil from the bed and banks of the pond, enabling it to be transported into the suction pipe by the flow generated by the slurry pump(s). During operation the dredge's cutter and suction pipe are lowered to the pond floor and are moved across the cut face using winches with forward mounted wires. The rear of the dredge is held in place using a spud pole. The cut material is transported hydraulically by pipeline.

The dredge that was used at the EHM was a diesel-powered, Neumann-built bucket-wheel type cutter suction dredge, which used a bucket-wheel type cutter mechanism. The dredge was fitted with a fixed and travelling spud assembly, which improves dredging accuracy and increases operational efficiency by reducing the time required to change the position of the dredge.

As neither of the two TSFs had a decant pond on its surface, it was necessary to excavate a starter pond prior to commencement of dredging. A ramp was also excavated at the edge of the starter pond, where the dredge could be assembled and set up for launch. The ramp was about $60 \mathrm{~m}$ long and $15 \mathrm{~m}$ wide, with a 1 in 15 grade. Following the assembly of the dredge, the starter pond was filled with water, and a dozer was used to push the dredge out onto the pond. A minimum pond depth of around $2 \mathrm{~m}$ is required for the particular dredge used on this project.
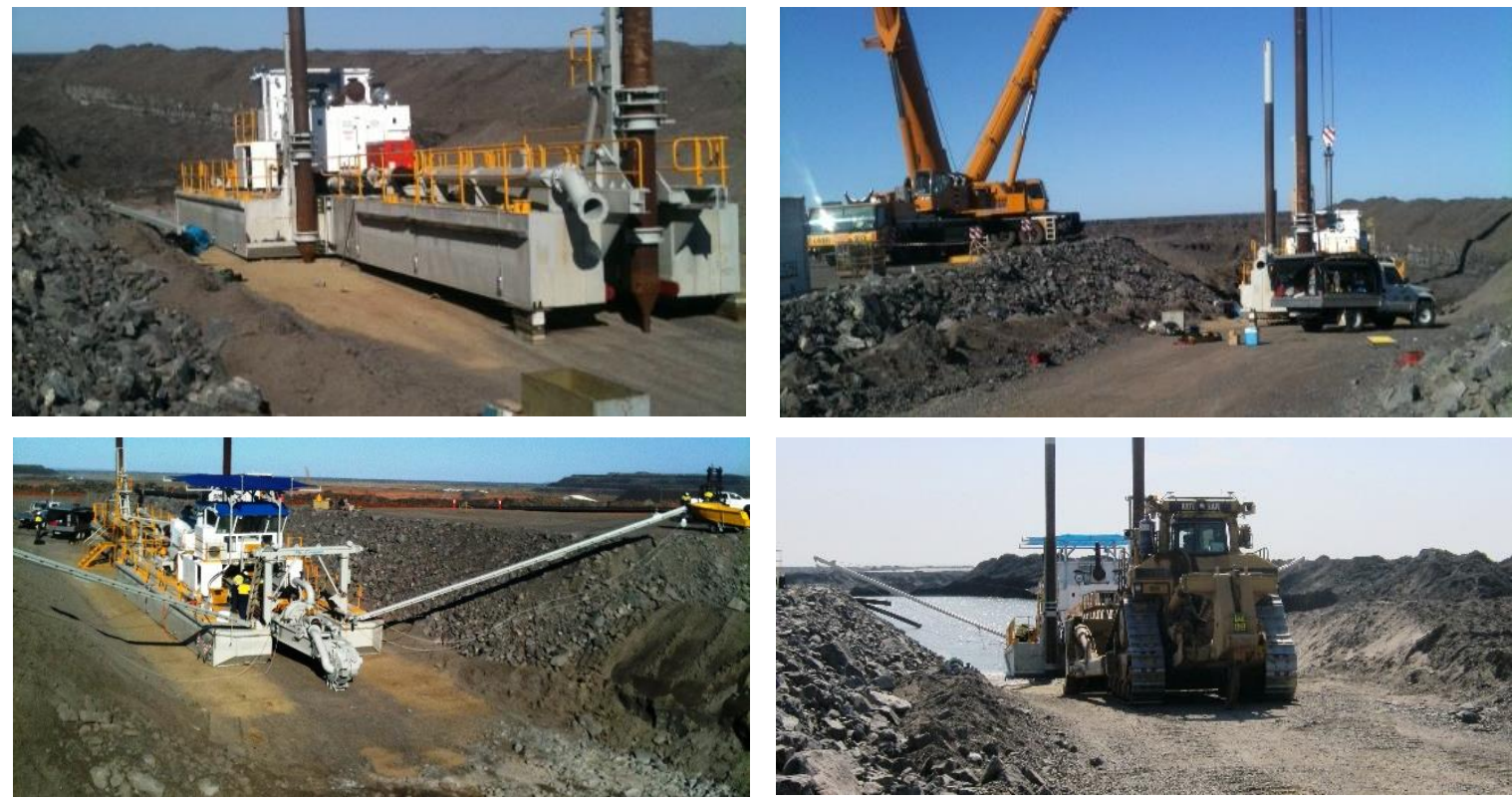

Figure 2 The dredge being assembled on the ramp after mobilisation to site. Once the starter pond had been filled, a dozer was used to push the dredge into it 


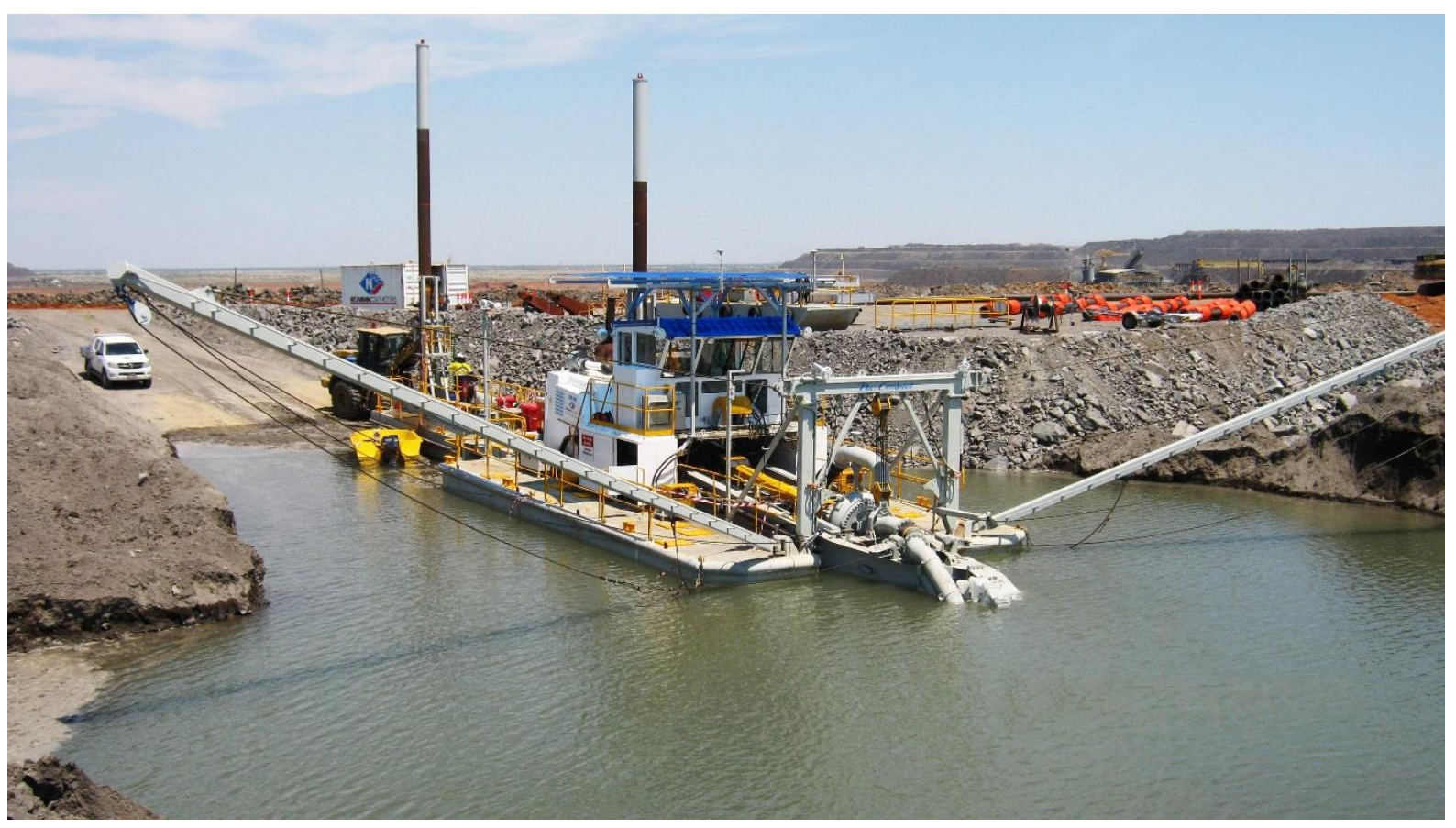

Figure 3 The dredge being pushed into the starter pond

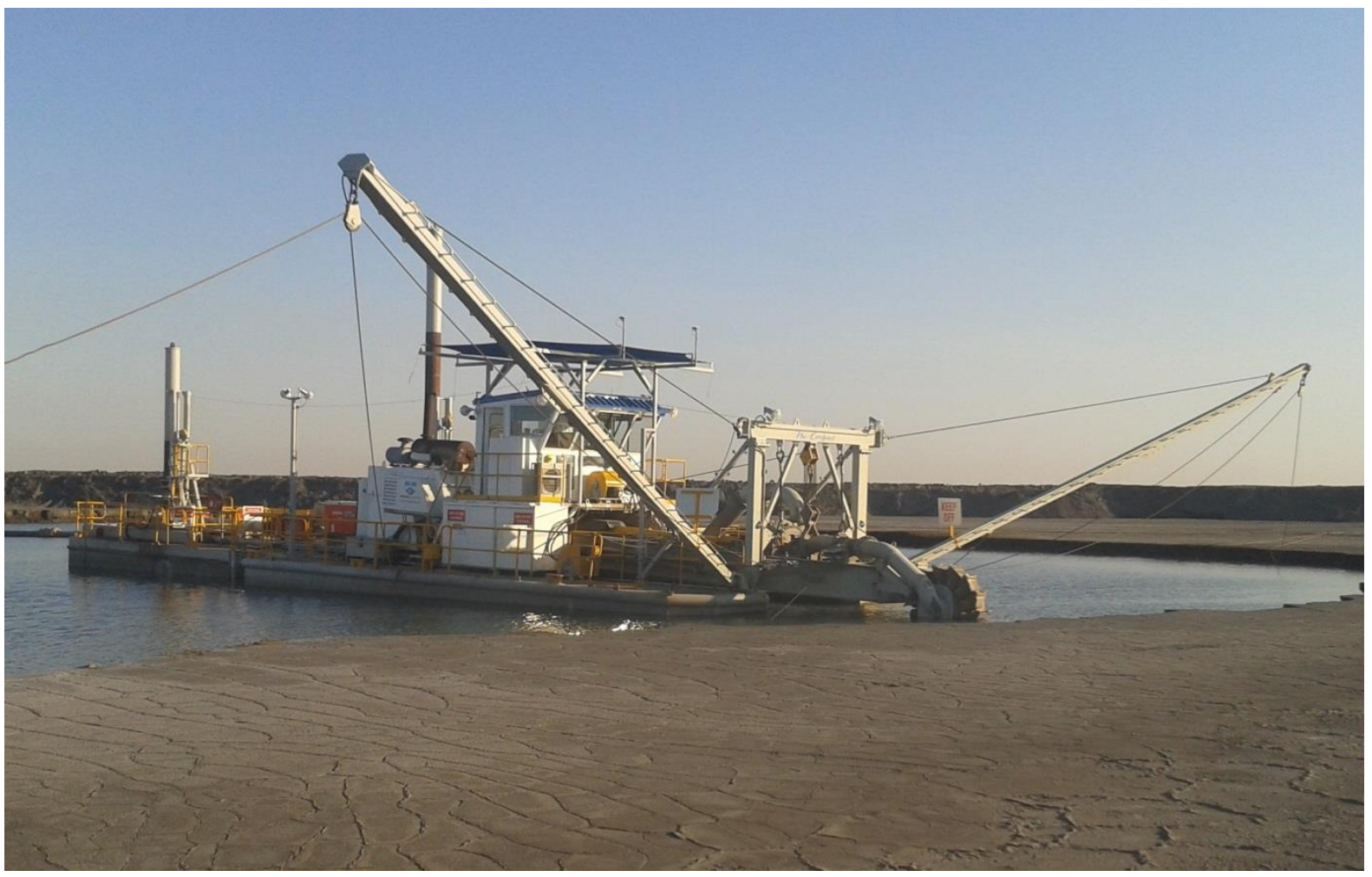

Figure 4 A photograph of the dredge at work. The bucket-wheel cutter has been raised above the pond surface, and can be seen at the front of the dredge

\section{$4 \quad$ Pumping requirements}

The client's required extraction rate was 400 tph of tailings to be delivered to the magnetite circuit at a target solids concentration of $35 \%$ (by weight). This is equivalent to Mtpa. The feed was required to be delivered at a steady volumetric flow rate and at reasonably steady solids concentration. 
The dredge was equipped with a Warman $10 / 8 \mathrm{GH}$ slurry pump and had sufficient capacity to transport the tailings/water mixture the horizontal distance of approximately 1,500 m through a $300 \mathrm{~mm}$ diameter polythene pipeline. The dredge pond on the tailings dam was approximately $20 \mathrm{~m}$ higher than the slurry discharge point into the magnetite circuit.

The slurry flow rate was controlled with a programmable logic controller (PLC) that received data from an on-board flow meter and adjusted the pump speed to automatically maintain the selected flow rate set point. The flow meter had to be of a type that did not suffer signal interference from the highly magnetic material, so the conventional mag-flow instrument could not be used. A Krohne Sonartrac unit was selected, which functions on the basis of detecting the velocity of eddies in a pipe using sonic measurements.

The density of the dredged slurry was controlled by another PLC circuit to automatically add dilution water to the dredge's suction pipe using feedback from the on-board nuclear density meter to control the speed and discharge valve position of a clear water pump. Density control was further improved by optimising operator technique and cutting pattern.

Back at the EHM process plant, it was necessary to pump return water back to the dredge pond at a greater flow rate than the incoming dredge cuttings, not only to enable the dredge to keep afloat, but also to enable the dredge pond to continue to grow, and to compensate for seepage and evaporation losses. The level of the dredge pond was able to be controlled by varying the amount of return water being pumped into the pond.

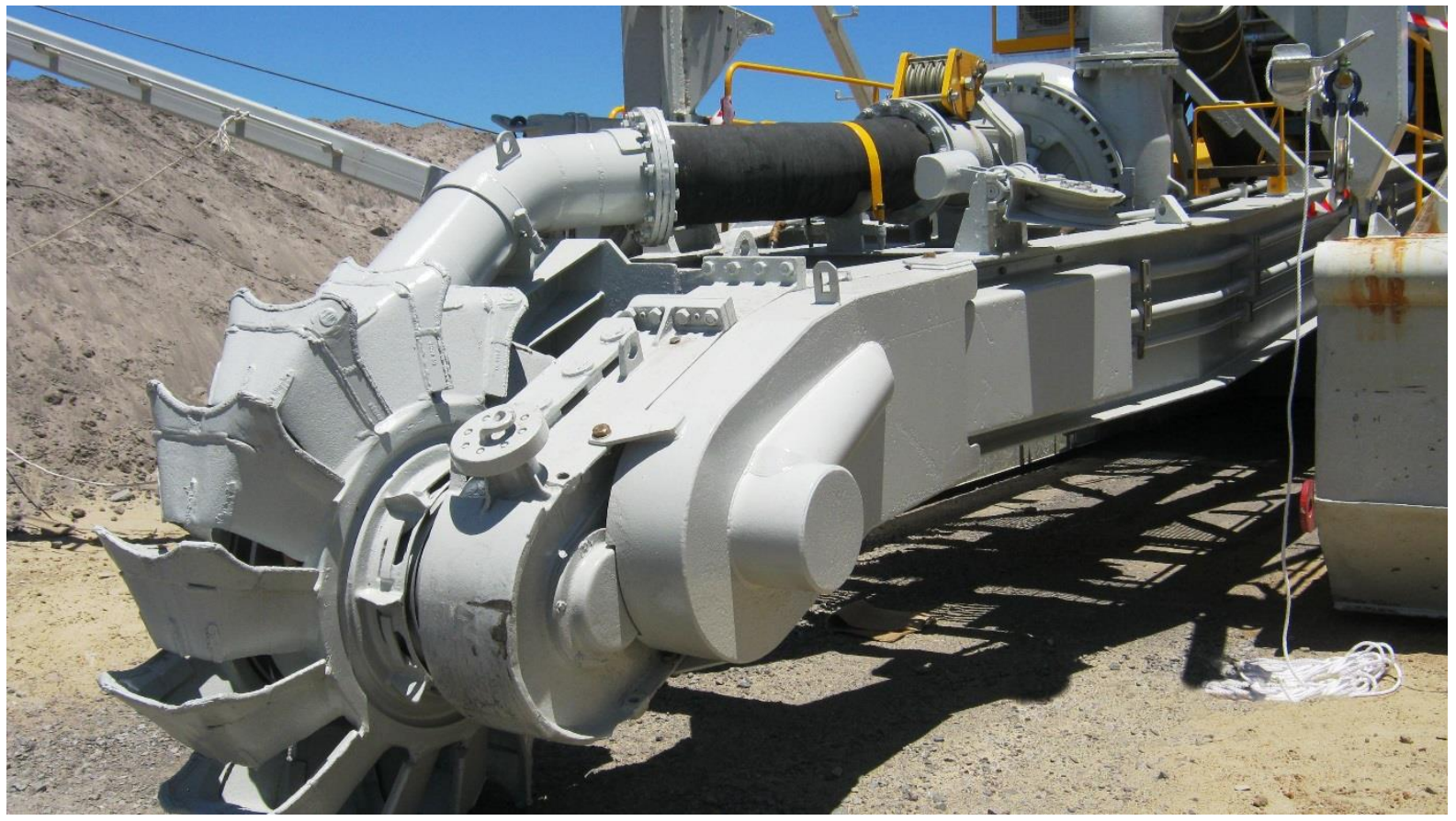

Figure 5 The bucket-wheel cutter head of the dredge, with the on-board centrifugal pump visible at the far end of the black flexible hose

\section{$5 \quad$ Management of the tailings discharge during dredging}

Active tailings discharge was occurring in the same cell that was being dredged. The training bunds that EHM had already constructed were exploited for keeping the active discharge from entering the dredge pond. A certain amount of sterilisation of magnetite-rich tailings was occurring in the adjacent deposition area, with barren tailings being deposited above it. However, the plan was to minimise this sterilisation by constructing underwater bunds in the dredge pond, and discharging the barren tailings in the mined out portion of the pond at the earliest possible opportunity. Such underwater bunds can be constructed by 
simply reducing the cutting depth along a chosen profile, and then returning to the desired cutting depth after the underwater bund has been created.

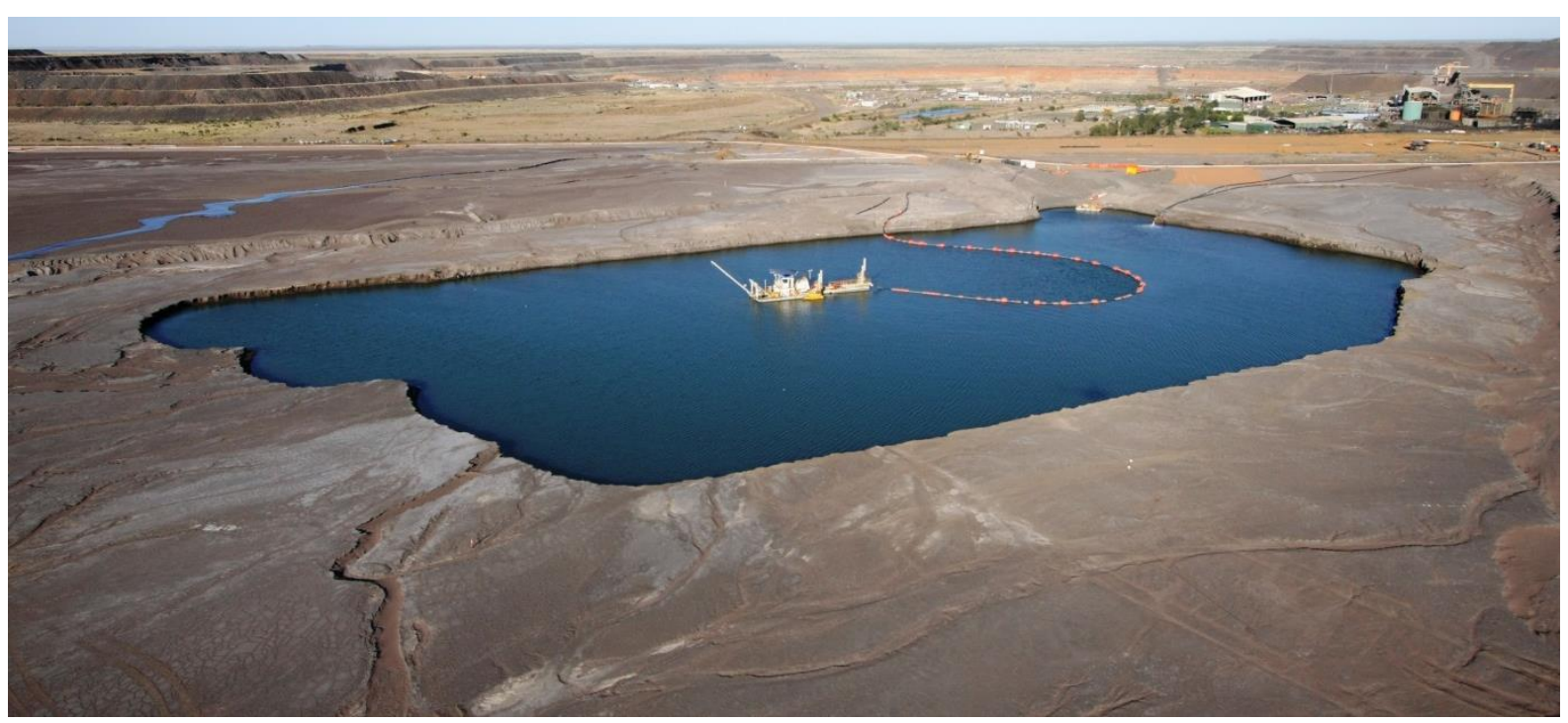

Figure 6 An aerial photograph of the dredge pond. On the far side of the pond the training bund can be seen, with an active tailings channel running beyond it

\section{$6 \quad$ Managing a dredging pond on a sloping beach}

Due to the $0.8 \%$ average slope of the tailings beach, it was necessary to start dredging at the high end of the beach and progress the pond towards the low end. This kept the freeboard down to a manageable height, thus reducing the risk of uncontrolled failures of the pond banks which could damage the dredge.

To manage this issue, the downslope length of the pond was kept within manageable limits, so that the differential in freeboard did not become excessive.

Access to the dredge pond for personnel and equipment also needed to be managed as the dredge pond moved down the slope. This was achieved by progressively extending the access ramp and shifting the access jetty at the upper end of the pond. 


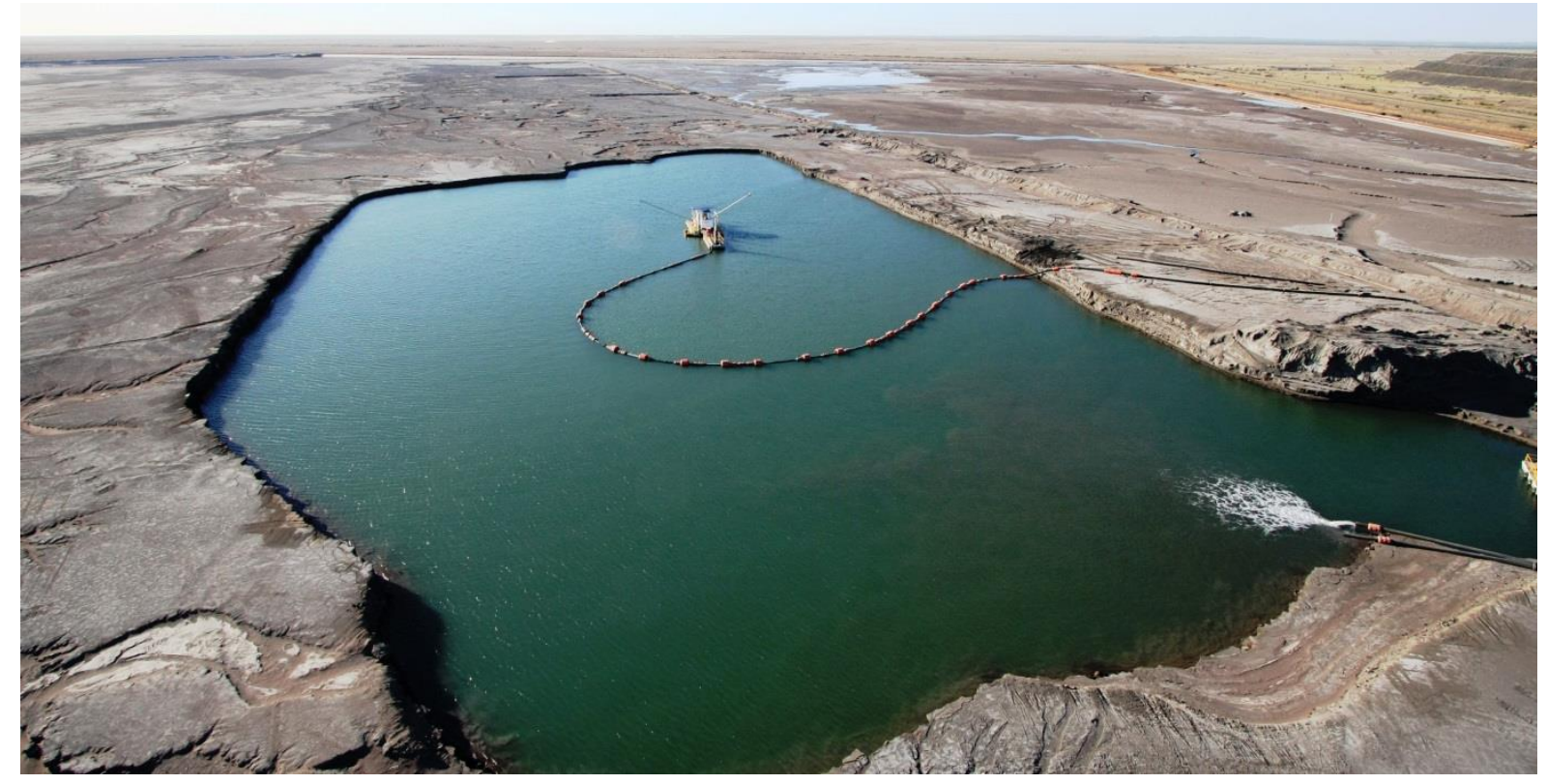

Figure 7 Another aerial photograph of the dredge pond. The freeboard at the far end of the pond is lower than at the near end, as a result of the beach slope. Return water is seen being discharged into the pond

\section{$7 \quad$ Navigation of the dredge}

Navigation of the dredge was enabled with a Trimble HYDROpro Real Time Kinetics (RTK)/Differential Global Positioning System (DGPS) on board the vessel. Coupled with other equipment such as a clinometer to sense the angle of the suction pipe, the position of the dredge's cutter was able to be continuously determined to a high level of accuracy. A predetermined dredging pattern was loaded into the dredge's navigation system computer, enabling the operator to accurately guide the cutter in accordance with the plan. The actual position of the dredge's cutter was recorded and stored for quality assurance purposes.

Control of the movement of the dredge was provided with spuds and two anchor rope slewing winches. The rear main spud could be hydraulically translated to step the vessel forward, as it is mounted on a carriageway that can be moved forward and aft. Once the carriageway reached its full travel the forward auxiliary spud could be lowered, the main spud retracted and relowered, then dredging could resume. Each of the two anchor rope slewing winches could be used to pivot the front of the dredge about the spud axis. This made the vessel cut in a series of horizontal arcs.

Anchoring of the dredge's forward slewing ropes was achieved by fastening each of the anchor ropes to an anchor positioned well clear of the dredge pond, either on the TSF walls or on the tailings themselves. Wide positioning of the anchors improved operational efficiency by reducing the frequency of anchor shifts. 


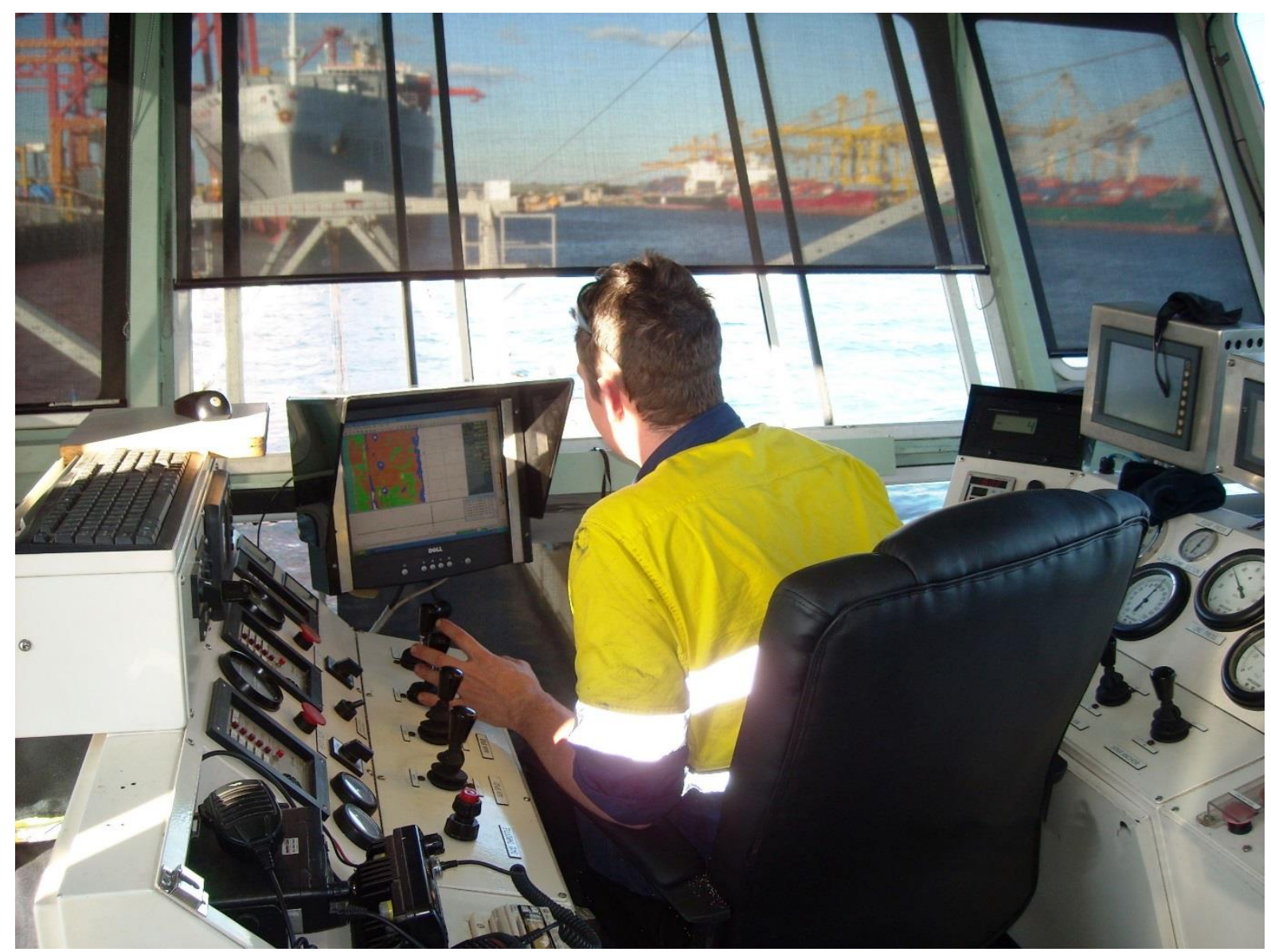

Figure 8 The dredge operator watching the navigation screen (photo not taken at EHM)

\section{Conclusions}

This case study has demonstrated that dredging can be an effective and economical means of extracting tailings from a TSF, even in a case where thickened tailings have been discharged to create a sloping beach, and where the storage must remain active during the dredging operation.

Several advantages of dredging over dry mining should also be noted here: a dredging operation is not weather sensitive; it eliminates dust problems; haul roads are not required; mobile equipment conflicts are virtually eliminated; and fewer personnel are required.

\section{Acknowledgement}

The authors wish to express their gratitude to the Ernest Henry Mine for their permission to publish this work. Particular thanks goes to Nathan Bullock, who managed the dredging project for EHM. 